\title{
Establishment of a blue light damage model of human retinal pigment epithelial cells in vitro
}

\author{
G. Su${ }^{1}$, S.J. Cai ${ }^{1}$, X. Gong ${ }^{2}$, L.L. Wang ${ }^{3}$, H.H. Li $^{4}$ and L.M. Wang ${ }^{1}$ \\ ${ }^{1}$ Department of Ophthalmology, \\ The Affiliated Hospital of Zunyi Medical University, \\ The Hospital of Guizhou Province, Zunyi, China \\ ${ }^{2}$ Department of Ophthalmology, \\ Jinan Third People's Hospital, Jinan, Shandong, China \\ ${ }^{3}$ Department of Ophthalmology, \\ Zunyi City First People's Hospital, Zunyi, Guizhou China \\ ${ }^{4}$ Department of Ophthalmology, \\ Yan'an City People's Hospital, Yanan, Shanxi, China \\ Corresponding author: S.J. Cai \\ E-mail: caishanjj_1@163.com
}

Genet. Mol. Res. 15 (2): gmr.15028092

Received November 18, 2015

Accepted February 11, 2016

Published June 24, 2016

DOI http://dx.doi.org/10.4238/gmr.15028092

\begin{abstract}
To establish a blue-light damage model of human retinal pigment epithelium (RPE). Fourth-generation human RPE cells were randomly divided into two groups. In group $\mathrm{A}$, cells were exposed to blue light (2000 $\pm 500 \mathrm{lux})$ for 0 (control), 3, 6, 9, and $12 \mathrm{~h}$, and cell culture was stopped after $12 \mathrm{~h}$. In group B, cells were exposed to blue light at the same intensity and time periods, but cell culture was stopped after $24 \mathrm{~h}$. TdT-mediated dUTP nick-end labeling (TUNEL) assay was performed to determine the most suitable illuminating time with apoptotic index. Flow cytometry was used to determine apoptotic ratio of RPEs. In group A, the apoptotic index of cells that received 6 , 9 and $12 \mathrm{~h}$ of blue light was higher than that of control. The apoptotic index of cells receiving 9 and $12 \mathrm{~h}$ was higher than that of $6 \mathrm{~h}(\mathrm{P}=$ $0.000)$. In group $B$, the apoptotic index and RPE cell apoptosis ratio of
\end{abstract}


cells exposed to 6,9 and $12 \mathrm{~h}$ of blue light were higher than that of $3 \mathrm{~h}(\mathrm{P}$ $=0.000$ ); and cells receiving 9 and $12 \mathrm{~h}$ had higher values than that of $6 \mathrm{~h}$. This study demonstrated that the best conditions to establish a blue light damage model of human retinal pigment epithelial cells in vitro are 2000 \pm 500 lux light intensity for $6 \mathrm{~h}$, with $24 \mathrm{~h}$ of cell culture post-exposure.

Key words: Light-induced damage; Retinal pigmented epithelium; Apoptosis; Damage model

\section{INTRODUCTION}

Chronic light damage causes lesions in retinal pigment epithelium (RPE) and Bruch's membrane, and exacerbates age-related macular degeneration, which is an important pathological basis in the occurrence and development of choroidal neovascularization (CNV) (Kernt et al., 2010). During atrophy, degeneration, and damage of the retina, cells die via apoptosis (Wenzel et al., 2005). Lipofuscin, the product of the outer segment of photoreceptor cells, produce auto-fluorescence, which when exposed to blue light, fluoresces. This is the basis for establishing blue light damage models of RPE cells in vitro. This study investigated the method of establishing light damage model of RPE cells in vitro, which would be important for investigating the mechanisms of blue-light-induced apoptosis in RPE cells.

\section{MATERIAL AND METHODS}

\section{Materials}

\section{Cell sources ethics statement}

RPE cells were collected from two healthy men (Cai et al., 2005), aged 25 and 35, who passed away due to accidents. We obtained the eyes within $12 \mathrm{~h}$ of death; the procedures were within the ethical standards established by the unit's human trials Committee.

\section{Reagents and instruments}

Reagents and instruments used in the study were as follows: Dulbecco's modified Eagle's medium nutrient mixture F-12, trypsin, paraformaldehyde (Sigma, Germany); fetal bovine serum (Hyclone, USA); TUNEL apoptosis assay kits (Roche, USA); IX7r0-142 inverted optical microscope (Olympus, Japan); micropipetter (Eppendorf, Germany); medical blue light tube (Yingze, Tianjin); TES1330A luminance meter (Taiguang, Taipei); high speed refrigerated table top centrifuge (5804R, Eppendorf, Germany); Beckman Gallios flow cytometer (Beckman, USA).

\section{Methods}

\section{Primary cell culture}

Primary RPE cells were cultured as described previously (Cai et al., 2005). Briefly, eyeballs were excised via pars plana, which is located 5-6 mm from the back of the corneal 
limb. The anterior segment was discarded, followed by vitrectomy and removal of the retinal neuroepithelium. The RPE cells were digested with $0.25 \%$ trypsin and $0.02 \%$ EDTA, and were seeded at a density of 50,000 cells $/ \mathrm{mL}$ with complete medium including $20 \% \mathrm{FBS}, 100$ $\mathrm{U} / \mathrm{mL}$ penicillin, $100 \mu \mathrm{g} / \mathrm{mL}$ streptomycin, and $0.3 \mathrm{mg} / \mathrm{mL}$ glutamine. Cells were incubated in culture dishes $\left(50 \mathrm{~cm}^{2}\right)$ at $37^{\circ} \mathrm{C}$ and $5 \% \mathrm{CO}_{2}$. RPE cells were subcultured when they grew confluent, and cells were used for experimentation after 4 passages. The RPE cells in each control group came from the same individual and cell passage.

\section{Immunohistochemistry detection of the RPE cells}

RPE cells were grown on glass cover slips $(2 \times 2 \mathrm{~cm})$ prior to fixation with acetone. Cells were permeated with $0.1 \%$ Triton X-100 (diluted with $0.1 \%$ sodium citrate), and were stained with primary mouse anti-human keratin antibodies and bio-labeled goat anti-mouse secondary antibodies conjugated to 3,3'-diaminobenzidine. Coverslips were washed with tap water, followed by deionized water. Lastly, slides were coated and imaged.

\section{Light treatment of RPE cells}

Fourth-generation human RPE cells were randomly divided into two groups. Group A: RPE cells were exposed to blue light with the intensity of $2000 \pm 500$ lux; cells were cultured for $12 \mathrm{~h}$ after exposure. Group B: cells were exposed to the light with an intensity of $2000 \pm$ 500 lux; cells were cultured for $24 \mathrm{~h}$ after light exposure. Groups A and B were subdivided into the following groups: A0 and B0 (no light exposure), A3 and B3 (light exposure for $3 \mathrm{~h}$ ), $\mathrm{A} 6$ and B6 (6 h), and A12 and B12 (12 h).

A medical blue light tube $(450 \pm 20 \mathrm{~nm}, 20 \mathrm{~W})$ was placed on a special framework, and the TES1330A illuminometer was used to measure the light intensity at the cell surface. Distance between the tube and the cell surface was adjusted according to light intensity. To ensure a stable growth environment for RPE cells, the blue light device was placed inside the $\mathrm{CO}_{2}$ incubator. Temperature was kept between 36.5 and $37.5^{\circ} \mathrm{C}$.

\section{Terminal deoxynucleotidyl transferase mediated dUTP nick end labeling (TUNEL) staining}

Glass coverslips with RPE cells were prepared as mentioned above. Cells were permeated with $0.1 \%$ Triton $\mathrm{X}-100$, for $5 \mathrm{~min}$ at $25^{\circ} \mathrm{C}$ followed by the addition of $50-\mu \mathrm{L}$ TUNEL reaction-solution to each cover slip. Cells were incubated for $60 \mathrm{~min}$ at $37^{\circ} \mathrm{C}$ in a wet box. The coverslips were then washed in PBS for $3 \min 3$ times, and $50 \mu \mathrm{L}$ of alkaline phosphatase (ALP) convert agent, Converter-AP, was added to each cover slip. Cells were incubated for $30 \mathrm{~min}$ at $37^{\circ} \mathrm{C}$, followed by the addition of 1:50 NBT/BCIP (diluted with substrate buffer) for $10 \mathrm{~min}$ at room temperature. The coverslips were washed with tap water, counterstained, dried, and coated. Finally, $1 \mathrm{mg} / \mathrm{mL}$ deoxyribonuclease was added to TUNELpositive coverslips and allowed to react for $10 \mathrm{~min}$.

\section{Apoptotic index (AI)}

Ten fields were randomly chosen at 100X magnification, and the average percentage of apoptotic RPE cells were calculated as the apoptotic index. 


\section{Flow cytometry}

RPE cells were stained with Annexin V-FITC/PI according to manufacturer instructions. PI $(250 \mu \mathrm{g})$ was diluted in $1 \mathrm{~mL}$ Annexin $\mathrm{V}$ binding buffer (diluted $2 \mathrm{X}$ with distilled water). RPE cells were digested and collected, then centrifuged at $1000 \mathrm{rpm}$ at $4^{\circ} \mathrm{C}$. Cells were washed twice with cold PBS ( $\mathrm{pH} 7.4$ ); the supernatant was discarded, and cells were re-suspended in cold Annexin V binding buffer at a concentration of $1 \times 10^{5}-10^{6}$ cells $/ \mathrm{mL}$. FITC Annexin V $(5 \mu \mathrm{L})$ and PI $(5 \mu \mathrm{L})$ were added to $490 \mu \mathrm{L}$ cell suspension, which was gently vortexed and allowed to incubate for $15 \mathrm{~min}$ on ice in the dark. Cells were analyzed by flow cytometry. The pass-band filter for excitation was set at $448 \mathrm{~nm}$; emission of FITC and PI were detected at $488 \mathrm{~nm}$ and $515 \mathrm{~nm}$, respectively.

\section{Statistical analysis}

Statistical analyses were performed using the SPSS software (version 16.0). Data are reported as means \pm standard deviation. Apoptotic indices (AIs) of RPE cells with different exposure times were analyzed with one-way analysis of variance. When the variances were equal, 2:2 comparison by least-significant difference (LSD) was conducted. Comparisons by the Dunnett test was performed when sample variances were unequal. Statistical significance was achieved when $\mathrm{P}<0.05$.

\section{RESULTS}

\section{TUNEL assay}

The results of TUNEL assay were showed in Figures 1 and 2.

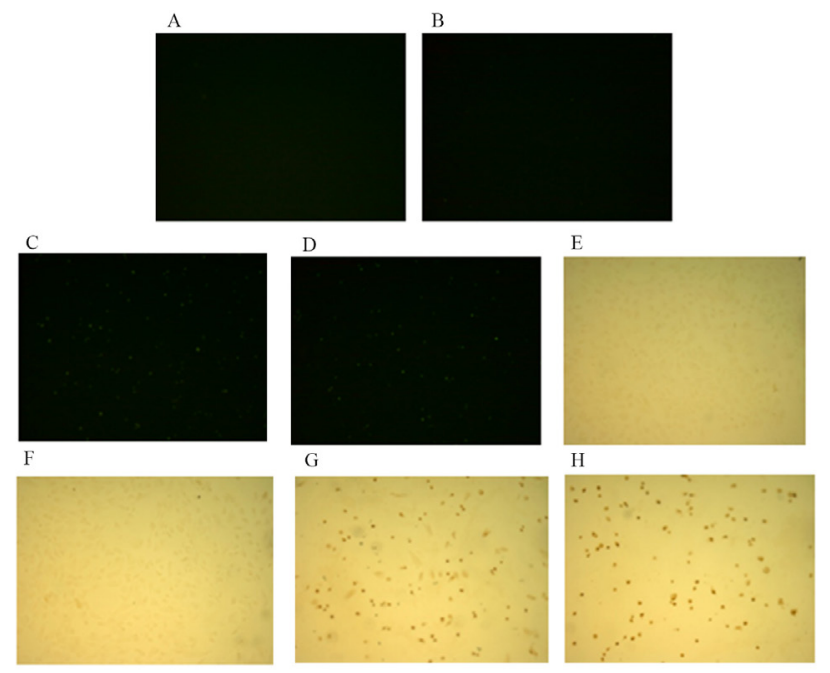

Figure 1. Cell apoptosis and necrosis analyzed by TdT-mediated dUTP nick-end labeling (TUNEL), diaminobenzidine (DAB) staining in RPE cells of A12 and B12 groups. Cultured cells were exposed to $2000 \pm 500$ lux blue light for $3(\mathbf{A}, \mathbf{E}), 6(\mathbf{B}, \mathbf{F}), 9(\mathbf{C}, \mathbf{G})$, and $12(\mathbf{D}, \mathbf{H}) \mathrm{h}$. Cells were cultured for $12 \mathrm{~h}$ after light exposure. 


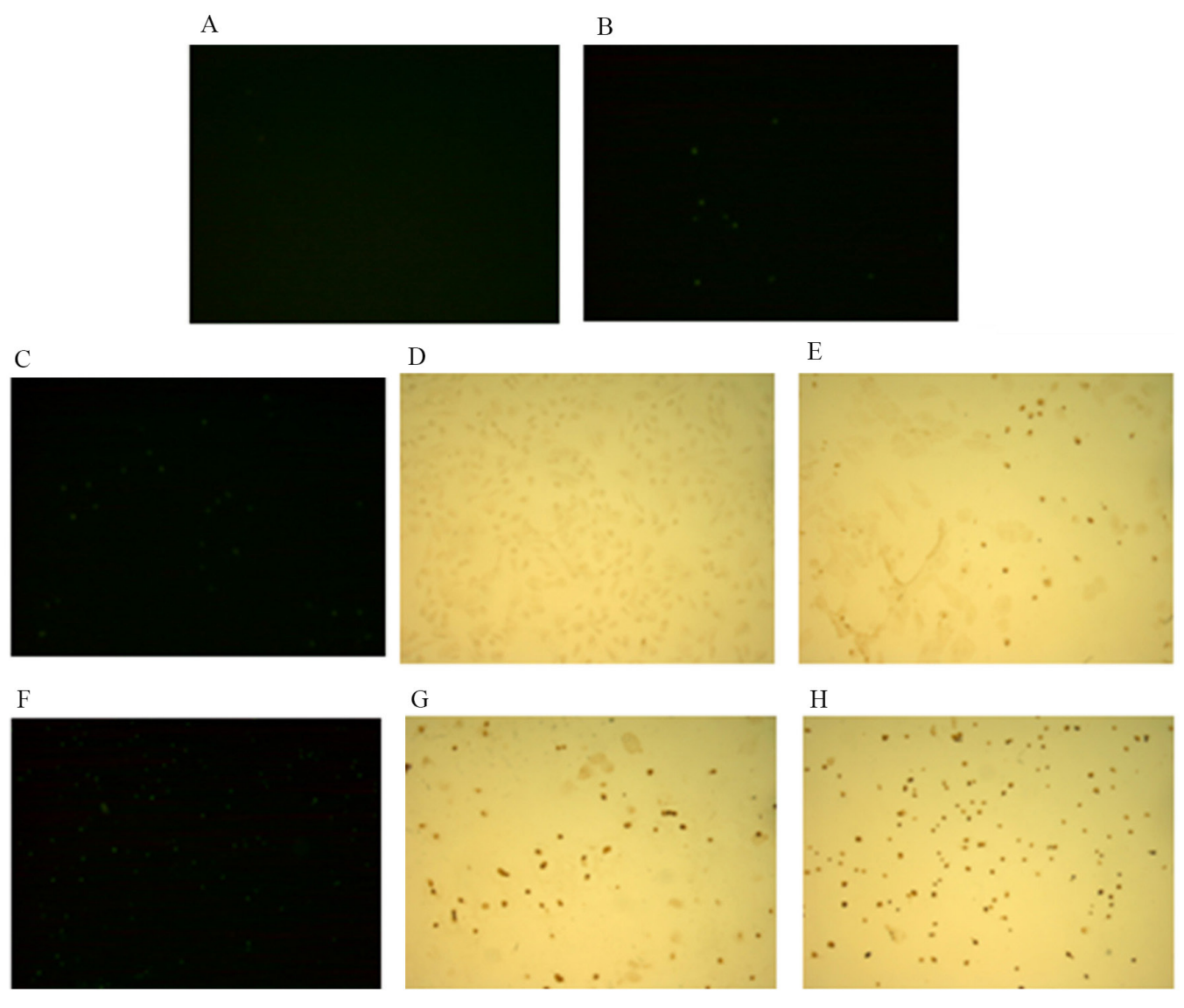

Figure 2. Cell apoptosis and necrosis analyzed by TUNEL and DAB staining in $24 \mathrm{~h}$ cultured RPE cells. Cultured cells were exposed to $2000 \pm 500$ lux blue light for $3(\mathbf{A}, \mathbf{E}), 6(\mathbf{B}, \mathbf{F}), 9(\mathbf{C}, \mathbf{G})$, and $12(\mathbf{D}, \mathbf{H}) \mathrm{h}$. Cells were cultured for $24 \mathrm{~h}$ after light exposure.

\section{AI}

\section{AI of subgroups cultured for the same duration}

In cells of group $\mathrm{A}$, which was cultured for $12 \mathrm{~h}$ after light exposure, the AI between A6, A9, and A12 differed significantly from that of $\mathrm{A} 0(\mathrm{P}=0.000)$. However, no difference was found between $\mathrm{A} 3$ and $\mathrm{A} 0(\mathrm{P}=0.162)$. In cells of group $\mathrm{B}$, which were cultured for $24 \mathrm{~h}$ after light exposure, AI was significantly increased in B3, B6, B9, and B12 when compared to that of the control group $(\mathrm{P}=0.000,0.000,0.000,0.000)$. As indicated by Table 1 , we also found that AI was significantly increased in B6, B9, and group B12 when compared to that of $\mathrm{B} 3(\mathrm{P}=0.000,0.000,0.000)$. 
Table 1. AI of subgroups cultured for the same time after different exposure time.

\begin{tabular}{l|c|c|c}
\hline Exposure time (h) & Fields $(\mathrm{N})$ & \multicolumn{2}{|c}{ AI index } \\
\cline { 3 - 4 } & & 12 -h culture & $24-\mathrm{h}$ culture \\
\hline 0 & 10 & $1.15 \pm 0.77$ & $0.83 \pm 0.57$ \\
\hline 3 & 10 & $2.88 \pm 1.73$ & $4.12 \pm 1.56^{*}$ \\
\hline 6 & 10 & $15.20 \pm 1.66^{*}$ & $50.93 \pm 1.60^{*}$ \\
\hline 9 & 10 & $52.81 \pm 2.51^{*}$ & $71.08 \pm 1.06^{*}$ \\
\hline 12 & 10 & $76.40 \pm 2.99^{*}$ & $90.45 \pm 0.80^{*}$ \\
\hline
\end{tabular}

$* \mathrm{P}<0.01$ compared with the control group. Data are reported as means $\pm \mathrm{SD}$.

\section{AI of subgroup exposed for the same time}

Intra-group comparisons between subgroups of group A showed that AIs were similar between cells in group A3, A9 and A12. However, difference in AI was detected between group A and B after $6 \mathrm{~h}$ of light exposure (Figure 3).

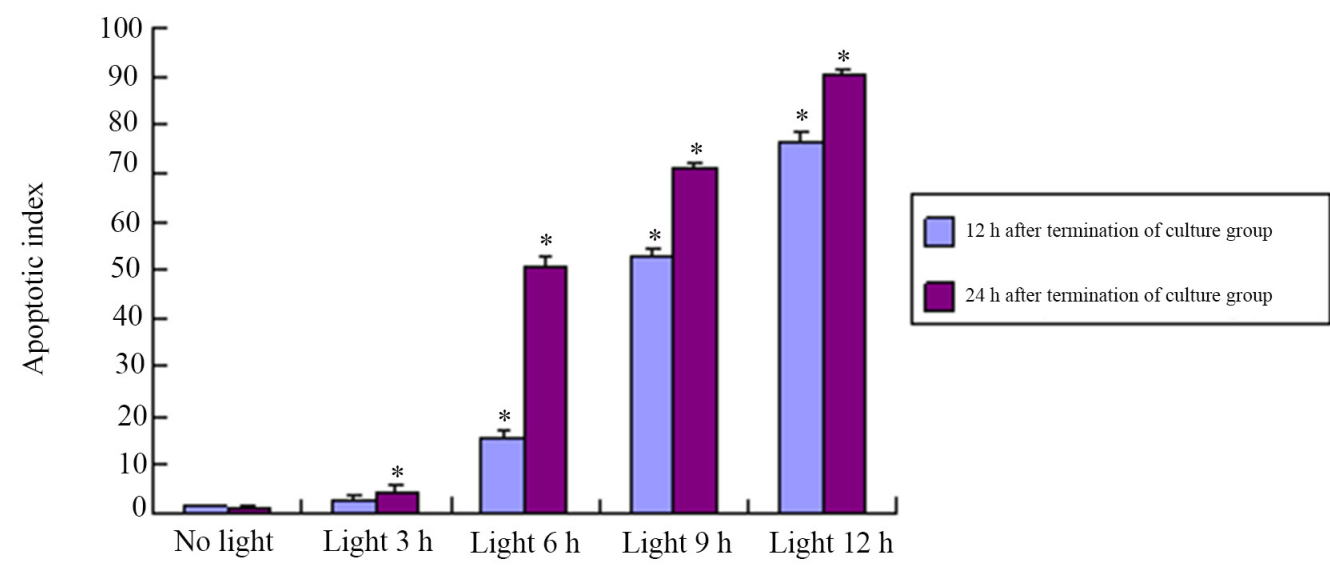

Figure 3. Subgroup AI analysis of same exposure time and different culture time. $* \mathrm{P}<0.01$ compared with the control group.

\section{AI of subgroup cultured for 24 h after exposure}

AIs of the 6-, 9-, and 12-h exposure subgroups were all found to be higher as compared to the 3-h exposure and the control subgroups $(\mathrm{P}=0.000,0.000,0.000,0.000,0.000,0.000)$. AIs of the 9- and 12-h exposure subgroup were found to be higher than the 6-h exposure subgroup $(\mathrm{P}=0.000,0.000)$. In addition, $\mathrm{AI}$ of the 12-h exposure subgroup was higher as compared with the 9 -h exposure subgroup $(\mathrm{P}=0.034)$ (Table 2, Figure 4$)$.

Table 2. AI of subgroups cultured for $24 \mathrm{~h}$ with different light exposure time.

\begin{tabular}{l|c|c}
\hline Exposure time $(\mathrm{h})$ & Sample $(\mathrm{N})$ & AI \\
\hline 0 & 10 & $13.03 \pm 2.95$ \\
\hline 3 & 10 & $16.70 \pm 1.60$ \\
\hline 6 & 10 & $40.70 \pm 0.88^{*}$ \\
\hline 9 & 10 & $71.80 \pm 2.23^{*}$ \\
\hline 12 & 10 & $76.60 \pm 3.41^{*}$ \\
\hline
\end{tabular}

$* \mathrm{P}<0.01$ compared with no exposure group. Data are reported as means $\pm \mathrm{SD}$. 
A

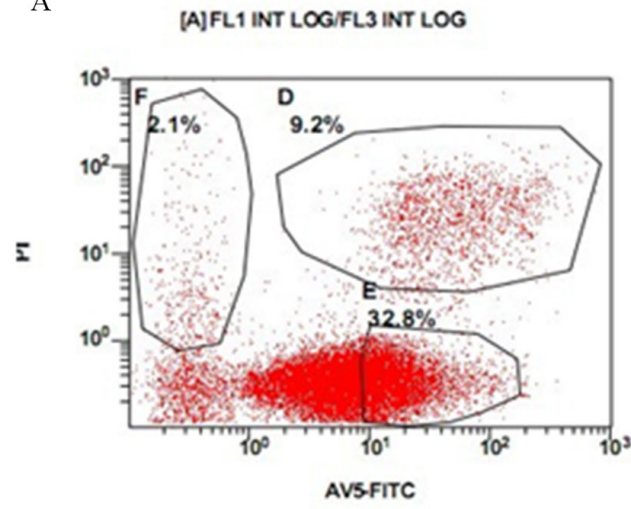

B

[A]FL1 INT LOG/FL3 INT LOG

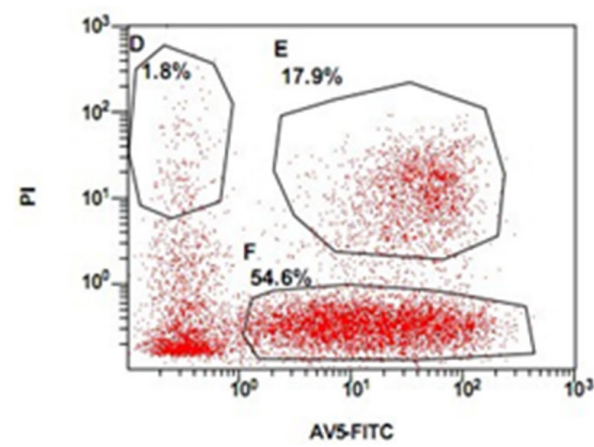

Figure 4. Scatter plot of retinal pigment epithelial cells in subgroups A6, B6, A9, and B9, as detected by flow cytometry. E indicates early apoptotic cells, D indicates late apoptotic RPE cells, and F indicates necrotic cells. The $\mathrm{x}$-axis indicates Annexin V fluorescent intensity; and y-axis, PI fluorescent intensity.

\section{DISCUSSION}

Though the eyes of human beings absorbs UV wavelengths below $400 \mathrm{~nm}$ through the cornea and the lens to protect the retina from high intensity ultraviolet (UV) light injury, the retina is still at risk for injury by visible light (Boulton et al., 2001). Studies showed that short wavelength radiation may damage the retina and can further aggravate age-related macular degeneration (Braunstein and Sparrow, 2005). In addition, free radicals and lipid peroxides have been shown to cause injury to RPE cells (Osborne et al., 2008). These injuries may be mediated by rhodopsin (Jang et al., 2005) among many other factors. Therefore, it is important to establish a light damage model of human RPE cells in vitro in order to study the pathogenesis of retinal degenerative diseases and age-related macular degeneration.

This study aimed to establish a stable blue-light damage model of human RPE cells in vitro. Following exposure to blue light, RPE cells cultured in vitro undergo morphological changes of apoptosis such as karyophy sepsis, hyperchromatic nuclear fragmentation, and becoming crescent or cap-shaped. Our experimental parameter included light intensity, exposure time, as well as culture time after light exposure. Cai et al. (2006) reported no significant difference between treatment groups exposed to light with an intensity of $500 \pm$ 100 lux and the control group, while an intensity of $2000 \pm 500$ lux is suitable for establishing the light exposure model. Roehlecke et al. (2009) showed that blue light with an irradiance of $1 \mathrm{~mW} / \mathrm{cm}^{2}$ would result in ROS production and changes in matrix metalloproteinase in RPE cells, but not apoptosis. Fu et al. (2010) established a regression equation of light intensity and light irradiance, where light intensity $(\mathrm{Lx})=$ light irradiance $\left(\mathrm{mW} / \mathrm{cm}^{2}\right)$ x $530.699+28.839$. Therefore, we set our light intensity at $2000 \pm 500 \mathrm{Lx}$ in this study, while varying the exposure and culture time.

In a previous study by Cai et al. (2006), RPE cells cultured in vitro were exposed to blue light with an intensity of $2000 \pm 500 \mathrm{Lx}$ for 6,12 , and $24 \mathrm{~h}$. Mitochondrial membrane potential and concentration of cytochrome $\mathrm{C}$ in the RPE cells were then examined. It was determined that after $6 \mathrm{~h}$ of light exposure, there was a reduction in mitochondrial membrane potential and an increase in cytochrome $\mathrm{C}$ concentration. In RPE cells cultured for 12, 24, and 
$36 \mathrm{~h}$ after $6 \mathrm{~h}$ of light exposure, increase in cytochrome $\mathrm{C}$ concentration has also been found. In order to study the appropriate exposure time and culture time after light exposure, cells in this study were exposed to blue light for 3, 6, 9, and $12 \mathrm{~h}$; cells were then cultured for 12 or $24 \mathrm{~h}$.

Fragmentation of chromosomal DNA during apoptosis is a gradual and phased process. When DNA undergoes double-stranded or single-stranded fragmentation, fluorescein sodium and DNA derivatives can be used to label the 3 '-terminal. Using TUNEL to stain apoptotic cells or apoptotic bodies in situ could reveal the typical biochemistry and morphological characteristics of cell apoptosis. Apoptosis of RPE cells were detected by TUNEL assays in this study. In group A, in which cells were cultured for $12 \mathrm{~h}$ after light exposure, RPE cells exposed to $9 \mathrm{~h}$ of blue light underwent morphological changes of apoptosis characterized by karyophy sepsis, hyperchromatic nuclear fragmentation, and development of crescent shapes. Increased exposure time was correlated to increased cell apoptosis and induction of necrosis. In group B, in which cells were cultured for $24 \mathrm{~h}$ after light exposure, RPE cells that experienced $6 \mathrm{~h}$ of light exposure also showed morphological changes of apoptosis. Similarly, greater light exposure time was followed by increased cell apoptosis and necrosis. We found that the AI of the subgroup cultured for $12 \mathrm{~h}$ after a 9-h light exposure was similar to that of the subgroup that was cultured for $24 \mathrm{~h}$ after a 6-h light exposure.

Phosphatidylserine (PS) is normally only found on the inner face of the plasma membrane in healthy cells. However, during early apoptosis, membrane asymmetry is lost, and PS translocates to the cell surface. This unique change is a marker of apoptotic cells. Once on the cell surface, PS can be easily detected with a fluorescent conjugate of Annexin V, a protein that has a high affinity for PS. Cell apoptosis can then be analyzed by flow cytometry. As PI binds to necrotic/dead cells, Annexin V-FITC and PI double staining can differentiate between apoptotic and necrotic cells. For the group that was cultured for $24 \mathrm{~h}$, there were more apoptotic cells and less necrotic cell in the 6-h light exposure subgroup as compared with the 9-h exposure subgroup.

In this study, we successfully established a blue light damage model of human RPE cells in vitro, and suggest that the optimal condition is $2000 \pm 500$ lux light intensity, 6-h light exposure, and $24 \mathrm{~h}$ of post-exposure culture. Using this parameter, we can establish an easily duplicated and stable blue light damage model of RPE cells (Gong et al., 2013; Wu et al., 2014). This will provide the experimental basis for future studies on the mechanisms of bluelight-induced apoptosis.

\section{Conflicts of interest}

The authors declare no conflict of interest.

\section{REFERENCES}

Boulton M, Rózanowska M and Rózanowski B (2001). Retinal photodamage. J. Photochem. Photobiol. B 64: 144-161. http://dx.doi.org/10.1016/S1011-1344(01)00227-5

Braunstein RE and Sparrow JR (2005). A blue-blocking intraocular lens should be used in cataract surgery. Arch. Ophthalmol. 123: 547-549. http://dx.doi.org/10.1001/archopht.123.4.547

Cai SJ, Yan M and Zhang JJ (2005). Blue-light-induced apoptosis of cultured human retinal pigment epithelial cells in vitro. Chin. J. Ocular Fundus Dis. 21: 384-387.

Cai SJ, Yan M, Mao YQ, Zhou Y, et al. (2006). Relationship between blue light-induced apoptosis and mitochondrial membrane potential and cytochrome $\mathrm{C}$ in cultured human retinal pigment epithelium cells. Zhonghua Yan Ke Za Zhi 42: 1095-1102. 
Fu M, Luan J and Feng LL (2010). Study of light source and light intensity in blue light damage model. Chin. Ophthalmic Res. 28: 399-400.

Gong X, Chai SJ, Li HH, Lv JP, et al. (2013). The effect of blue light on L-type calcium channel subunit mRNA expression of human retinal pigment epithelial cells cultured in vitro. Chin. J. Ocular Fundus Dis. 29: 411-415.

Jang YP, Matsuda H, Itagaki Y, Nakanishi K, et al. (2005). Characterization of peroxy-A2E and furan-A2E photooxidation products and detection in human and mouse retinal pigment epithelial cell lipofuscin. J. Biol. Chem. 48: $39732-$ 39739.

Kernt M, Neubauer AS, Liegl RG, Hirneiss C, et al. (2010) Sorafenib prevents human retinal pigment epithelium cells from light-induced overexpression of VEGF, PDGF and PIGF. Br. J. Ophthalmol. 94: 1533-1539.

Osborne NN, Li GY, Ji D, Mortiboys HJ, et al. (2008). Light affects mitochondria to cause apoptosis to cultured cells: possible relevance to ganglion cell death in certain optic neuropathies. J. Neurochem. 105: 2013-2028. http://dx.doi. org $/ 10.1111 / \mathrm{j} .1471-4159.2008 .05320 . \mathrm{x}$

Roehlecke C, Schaller A, Knels L and Funk RH (2009). The influence of sublethal blue light exposure on human RPE cells. Mol. Vis. 15: 1929-1938.

Wenzel A, Grimm C, Samardzija M and Remé CE (2005). Molecular mechanisms of light-induced photoreceptor apoptosis and neuroprotection for retinal degeneration. Prog. Retin. Eye Res. 24: 275-306. http://dx.doi.org/10.1016/j. preteyeres.2004.08.002

Wu ZP, Chai SJ, Lv JP, Li HH, et al. (2014). The effect of blue light on $\mathrm{Ca}^{2+}$-protein kinase $\mathrm{C}$ signaling pathway in human retinal pigment epithelial cells in vitro. Chin. J. Ocular Fundus Dis. 30: 245-249. 